China Perspectives

65 | may - june 2006

Varia

\title{
The Referendum Law 2003 in Taiwan: Not Yet the End of the Affair
}

Joseph Lee

\section{OpenEdition}

12 Journals

Édition électronique

URL : http://journals.openedition.org/chinaperspectives/633

DOI : 10.4000/chinaperspectives.633

ISSN : 1996-4617

Éditeur

Centre d'étude français sur la Chine contemporaine

Édition imprimée

Date de publication : 1 juin 2006

ISSN : 2070-3449

Référence électronique

Joseph Lee, "The Referendum Law 2003 in Taiwan: Not Yet the End of the Affair », China Perspectives [En ligne], 65 I may - june 2006, mis en ligne le 01 juin 2009, consulté le 28 octobre 2019. URL : http:// journals.openedition.org/chinaperspectives/633; DOI : 10.4000/chinaperspectives.633

Ce document a été généré automatiquement le 28 octobre 2019

(C) All rights reserved 


\section{The Referendum Law 2003 in Taiwan: Not Yet the End of the Affair}

Joseph Lee

1 There is still lack of clarity, and some controversy, as to the reasons behind the passing of the Taiwan Referendum Law 2003 (the Referendum Law). The Law was enacted with the declared intention to enhance direct democracy. However, it has been argued that there was also another agenda beyond mere improvement in the democratic system, which is to provide a legitimate way for Taiwan independence. Whatever the intention and purpose in passing the Referendum Law might have been, the author argues that the Referendum Law still poses some legal problems and should be further clarified and rectified. The problem arises because it is questionable whether the Referendum Law contains sufficient safeguards against the possible exercise of arbitrary power on the part of the Government. However, adequate safeguards are necessary in a system based on the rule of law. In such a system, the extent of the Government's power, and the way in which it exercises such power, is limited and controlled by law and, above all, by the Constitution ${ }^{1}$. The Government in all its actions is bound by fixed rules announced beforehand ${ }^{2}$. There should be clear rules and procedures for making laws. The independence of the judiciary has to be guaranteed to ensure that judges are free to decide cases based on the law and not in response to any external pressure ${ }^{3}$. Furthermore, the courts should have the power to review the way in which the abovementioned concepts are implemented to ensure that they are being operated as demanded by the rule of law.

2 The Referendum Law provides for three types of referendum: the national referendum ${ }^{4}$, the local referendum ${ }^{5}$, and the defence referendum ${ }^{6}$. First, the national referendum is a referendum on new legislation, an initiative on new legal principles, an initiative on or a ratification of major policies, and the ratification of constitutional amendments. The most controversial question relating to the national referendum is whether the referendum can and should be used for passing constitutional amendments or for 
adopting a new Taiwan Constitution ${ }^{7}$. Secondly, the local referendum is a referendum on the ratification of local regulations, initiative on principles of local regulations, initiative on or ratification of major local policies. Thirdly, the defence referendum is to be called by the President if, and only if, the country faces an external threat that is "likely" to cause change in her sovereign status ${ }^{8}$. Finally, there are limitations placed on the use of the referendum, for instance, a referendum shall not be called for budgetary issues, taxation, governmental investment, remuneration, and official appointments9.

3 In order to analyse what legal problems the Referendum Law poses in the existing legal system in Taiwan, this article will identify conflicts and tensions between the Referendum Law and the Taiwan Constitution. The analysis will include the original position of the Law under the Constitution and its position as a result of the subsequent Constitutional Amendment of June 10th 2005 (the 2005 Amendment). The 2005 Amendment may have made the Referendum Law compliant with the Constitution ex post. A further issue relates to the mechanism of legal control on the President's power to call a defence referendum. In addition, the analysis will include the discussion of the High Court's ruling in the case brought by Lien Chan and James Soong, the presidential candidates for the blue-camp in $2004^{10}$, to annul the election. These proceedings also generated interesting issues as regards the Referendum Law, particularly in relation to the calling of the defence referendum. Finally, this article will discuss whether any steps should be taken to rectify the current legal anomalies.

History of the Referendum Law 2003

4 The term referendum (gongtou) is not a completely new concept to the legal system in Taiwan and has appeared in important constitutional rulings. In 2001, the Democratic Progressive Party (DPP) Government decided to discontinue the construction of the fourth nuclear power plant. The Legislative Yuan commenced constitutional proceedings in the Constitutional Court ${ }^{11}$. In considering whether or not to adjudicate the case, the Court said that "whether to build the nuclear power plant or not is a political question, not a legal question. Therefore, it is not within the remit of the judiciary. The issue should be resolved through political negotiation or the procedures laid down by the Constitution. (Abroad, they resorted to referenda). This should be the proper way to resolve the issue. However, to meet the expectation of the Legislative Yuan, the Executive Yuan, and the majority of the people in Taiwan, we hereby accept to adjudicate the case". If there had been a referendum law, the dispute could have been resolved through a referendum and not through the Court. This case also indicates that a legal-political dispute over which the Court declines its jurisdiction may be referred for a referendum. In another case, the Constitutional Court, in expressing a view on a constitutional amendment, compared the amendment procedure in Taiwan with the procedures in other countries and regarded the "referendum" (gongtou) as a way in which people are able to be involved in "constitutional politics"12. This also further indicates that a referendum could be used for ratifying a constitutional amendment.

5 In 2003, legislators from the DDP introduced the Referendum Bill in the Legislative Yuan. Initially, this was fiercely opposed by the KMT, the People's First Party (PFP), and other independent legislators. The opponents of the Bill advanced the legal argument that if the Bill became law, it would be unconstitutional. The political argument was that the Bill, if it became law, would heighten the tensions in cross-Strait relations. 
Subsequently, the KMT and the PFP also introduced their own version of the Referendum Bill ${ }^{13}$. Although the KMT and the PFP together through their majority in the Legislative Yuan were able to outvote the DPP's Referendum Bill, political pressure required them not to oppose DPP's version of the bill totally but to negotiate. The provisions in the original Bill, introduced by the DPP, for referenda on change of the national frontiers, the national flag, and the official name of the country in addition to the national, local, and defence referenda, were removed ${ }^{14}$. The quorum (or the turnout threshold) originally envisaged in the Bill was increased. This was seen as victory by the KMT and the PFP and as a defeat of the DPP. The Premier Yu Shyi-kun, as he then was, in response to the enactment of the Referendum Law said that "this was a "birdcage referendum' intended to confine the exercise of the people's rights".

6 The passing of the Referendum Law in 2003 occurred against the background of the forthcoming presidential elections. By negotiating a watered-down version of the Bill, the KMT and the PFP thought that the election agenda would no longer be dominated by the referendum issue. However, and unexpectedly, President Chen Shui-bian called a defence referendum under Article 17 of the Referendum Law. The call for a defence referendum astonished the blue camp presidential candidates as well as the US Government. Needless to say, the news was also not expected by the People's Republic of China (PRC). Since then, the election agenda centred on the referendum. The blue camp campaigned against the defence referendum and argued that the referendum was moneywasting and dangerous to Taiwan's security. It also increased tensions between Washington and Taipei.

7 The Government of Taiwan argued that the referendum would affirm the status quo of Strait relations. To this purpose, two carefully drafted questions were published. The first was the following: "The People of Taiwan demand that the Taiwan Strait issue be resolved through peaceful means. Should mainland China refuse to withdraw the missiles it has aimed at Taiwan and openly to renounce the use of force against us, would you agree that the Government should acquire more advanced anti-missile weapons to strengthen Taiwan's self-defence capabilities?".

8 The second question was the following: "Would you agree that our Government should engage in negotiations with mainland China on the establishment of a "peace and stability" framework for cross-Strait interactions in order to build consensus and for the welfare of the peoples on both sides?"

9 The two questions reflect the Government's intention to affirm the existing understanding and expectations in the relationships with Washington and Beijing. The calculation was that both questions would receive "yes" votes as it was thought that no controversy existed as to the contents of the questions.

10 The first question would appear to be in the interest of the United States as the Taiwanese Government would receive backing by the electorate to procure more advanced weapons from the United States. This question would simply have reaffirmed the current arrangements between United States and Taiwan based on the Taiwan Relations Act and the practice of many years ${ }^{15}$. In case of a "yes" vote, if the blue campdominated Legislative Yuan had opposed Government's military procurement from the United States, this would have been seen as undemocratic. The United States could also be thought likely to be in favour of a "yes" vote on the question as the United States has been the biggest military provider to Taiwan ${ }^{16}$. 
11 The second question was drafted in a way that made it difficult for China and the United States to object to it. This is because the question sets no pre-condition for opening dialogue with China but only refers to a "peace and stability" framework, which could potentially include the controversial "one China principle".

12 The defence referendum was held on the Election Day and failed because the ballot did not meet the $50 \%$ quorum $^{17}$.

The Legal Status of the Referendum Law 2003 under the Constitution of the R.O.C, Taiwan

13 The Law states that a referendum (gongtou) may be called for the purposes of ratification (fujue) of laws, initiative (chuangzhi) on legislative principles, initiative on (chuangzhi) or ratification (fujue) of major policy, and ratification (fujue) of constitutional amendments ${ }^{18}$.

14 The first question is whether the Law is constitutional. This problem must be analysed by comparing the text of the Law and the Constitution. However, the problem is more than a semantic one. There is no doubt that the primary objective of the Law is to establish a legal mechanism to enable the people in Taiwan to repeal or introduce legal provisions that cannot be repealed or introduced by the central or local governments. A significant matter being that if the Law were to be held unconstitutional, the power exercised by the President to call the defence referendum would subsequently also be held unconstitutional or unlawful ${ }^{19}$.

The reason for questioning the constitutional validity of the Law is two-fold: first, there is a lack of reference to the Constitution; and secondly, some provisions under the Referendum Law conflict directly with certain provisions of the Constitution, especially as regards the use of the referendum on constitutional amendments. It is crucial to recognise the different concepts of "referendum" (fujue) ${ }^{20}$ under the Constitution, and "referendum" (gongtou) under the ordinary Referendum Law 2003 ${ }^{21}$. The Constitution does provide for the citizens' right of referendum. This is the "constitutional referendum". Article 17 of the Constitution provides that "the people shall have the right of election, recall, initiative (chuangzhi), and referendum (fujue)". Furthermore, Article 136 of the Constitution specifies that "the exercise of the rights of initiative and referendum shall be prescribed by law" 22 . That is to say, that any ordinary law enacted for the purpose of the exercise of the right of referendum must be subject to these articles of the Constitution. It follows that any law providing for a referendum must be based on these particular provisions rather than introducing a totally new right neither prohibited nor protected by the Constitution. However, the Referendum Law does not refer to Article 17 or to Article 136 of the Constitution. The only reference to the Constitution is made in Article 1 of the Referendum Law, which states that the Law is enacted based on the constitutional principle that sovereignty belongs to the people ${ }^{23}$. It may be argued that the lack of any specific reference to specific Articles of the Constitution makes the Law less vulnerable to be challenged in the Constitutional Court because it would fall to be assessed only against the general constitutional principles rather than against specific constitutional provisions. This argument, however, would appear to be weak. The better view is that, notwithstanding the lack of reference to the relevant constitutional provisions, unless and until Article 17 and Article 136 of the Constitution are abolished, the Law should be interpreted as enacted for the exercise of the rights of initiative and referendum provided by these articles. On this analysis, the Law does fit within the constitutional framework as it is enacted to give effect to 
articles 17 and 136. However, when the Referendum Law is assessed against the provisions of the Constitution in force at the time when the Law was passed, major problems arise. The referendum (gongtou) for purpose of ratifying (fujue) constitutional amendments provided for by the Referendum Law would appear to have been in direct conflict with the constitutional provisions that empowered the National Assembly to have the final say (fujue) regarding any constitutional amendments. Although the National Assembly at the time was not convened, it remained a political institution that had the power to ratify amendments to the Constitution. During the election campaign, the DDP promised to hold a referendum under the Referendum Law to introduce a wholly new Constitution. This was proved to be inconceivable without violating the Constitution, as was subsequently conceded by President Chen Shui-bian in this inaugural speech on May 20th $2004^{24}$.

The legally binding effect of the referendum

This section examines the legal effect of a referendum. The author argues that there is lack of clarity as to the legal effect of a referendum. Chapter 4, Article 30 of the Referendum Law provides that the referendum question is regarded as approved, first, if there is a greater than $50 \%$ turnout of the total number of registered voters and, secondly, if the majority of actual voters cast "yes" votes ${ }^{25}$. It is also stated that the question of the referendum is deemed "rejected" if the turnout is less than $50 \%$ of the total number of registered voters or the majority of voters casts "no" votes. The Law makes no distinction between the failure of the referendum on the ground of quorum, where the $50 \%$ quorum is not reached, and the rejection of the proposal of the question when the quorum is met but the majority votes "no" to the question. However, in principle, these two different outcomes should have different legal consequences. If the referendum is binding and fails on the ground of quorum, the Government may take the course of action envisaged in the question but is not bound to any particular course of action. However, if the quorum is reached and there is a "no" vote to the question, the Government must not take the course of action envisaged in the question. This is the case, however, only if the referendum is binding. If, on the other hand, the Government, upon receiving a "no" vote on the issue, is still free to pursue the course of action envisaged in the question, the referendum is then said to be consultative. The Referendum Law is not clear on this point. The only legal consequence of the failure to reach the quorum or to secure a majority of "yes" votes, is that the same question or questions may not be raised within three years after the publication of the results of the referendum by the Central Election Commission ${ }^{26}$. However, if the result is not binding, there will be no legal consequences. The Government would still be free to pursue the policy put to the electorate whether this is against or consistent with the will of the people expressed in the referendum.

The question of the consultative or binding nature of the referendum is far from being of legal interest only. It has important political implications. Following the outcome of the defence referendum in March 2004, government officials in Taiwan clearly stated that the result of the referendum was not binding on the Government. It can be argued that the referendum only failed on the ground of lack of quorum but the policy was not "rejected" by the people in the referendum. But the Referendum Law does not make a distinction between a "no" vote and a failure to reach the quorum. Therefore, the current position advocated by the Government seems to imply that the referendum is not binding. If it were binding, the Government's new proposal to procure weapons 
from the United States, currently being contrasted by the opposition parties in the Legislative Yuan, would be in breach of the Referendum Law.

Referendum on constitutional amendments

18 Two aspects of the constitutionality of the Referendum Law need be analysed: before and after the 2005 Constitutional Amendment. Let us start with the position before the 2005 Amendment. As explained before, the Referendum Law is not clear on the question of the legal effect of the referendum. However, it would appear that, at least insofar as the referendum on constitutional amendments is concerned, at the time of passing the Referendum Law and until the 2005 Amendment was passed, if the result of the referendum under the Law was binding, then some provisions in the Law were unconstitutional.

Under the Referendum Law, a referendum (fujue) may be held for amending the Constitution, and such amendment may only be implemented in accordance with the procedure laid down in the Constitution ${ }^{27}$. The Constitution provided that the ratification of the amendment must be received by three-fourths of the delegates present at a meeting having a quorum of two-thirds of the entire National Assembly ${ }^{28}$. Therefore, if, for instance, a referendum is held to ratify a constitutional amendment such as the abolition of the Examination Yuan established by Article 83 of the Constitution, and the referendum receives a majority of "yes" votes with a $50 \%$ quorum, such an amendment proposal would still need to be submitted to the National Assembly for its ratification in order to take legal effect. If the result of such referendum is intended to have legally binding effect, and the National Assembly does not need to ratify such amendment, the referendum will be considered unconstitutional.

This likelihood of the Referendum Law provisions relating to the referendum on constitutional amendments being declared unconstitutional has been removed by the Amendment passed on June 10th 2005. The 2005 Amendment contains the following provisions: 1) voters in late 2007 will use a new "single district, dual vote" system to elect a Legislative Yuan that will be downsized to 113 seats from its current 225 seats; 2) the tenure of the new Legislative Yuan will be increased from the current three years to four years; 3) constitutional amendments shall be proposed by the Legislative Yuan but, after the mandatory 180-day promulgation period, shall be presented for ratification by all Taiwan eligible voters in a referendum; 4) the functional or ad hoc National Assembly, which is the legal body responsible for revising the Constitution as stipulated in amendments passed in May 2000, is abolished; 5) the Legislative Yuan has the power to launch a recall of the President and Vice-President. Such a recall can be proposed by one fourth of the legislators and must then be approved by two-thirds of the legislative body. It is then to be submitted to a nationwide referendum for ratification or rejection by majority vote; 6 ) the Legislative Yuan has the power to propose the impeachment of the President or Vice-President, but such a motion would be reviewed by the Council of Grand Justices and then adjudicated by a yet-to-be established Constitutional Court. More particularly, Article 12 of the 2005 Amendment states that the Constitution can be amended if: first, one-quarter of legislators proposes the amendment; second, threequarters of total legislators attend and three-quarters approve the amendment; and, third, half of approved votes is for amendment. Finally, the amendment could then be submitted to the people for ratification in accordance with the Referendum Law. It is clear that the National Assembly will no longer have a role in ratifying constitutional 
amendments. As a consequence, the Referendum Law is no longer unconstitutional after the 2005 Amendment.

The mechanisms of legal control on the President's power to call an Article 17 referendum (defence referendum)

21 Many believed that the defence referendum held on the presidential Election Day was a way to divert the election focus in the DDP's favour. Nevertheless, any election strategy is an inevitable element in a democratic election and should be accepted as long as it complies with the law.

The problems raised by the defence referendum are, first, the ambiguity of the wording of Article 17, and secondly, the inadequacy of the legal restraints on the exercise of the power to call a defence referendum ${ }^{29}$. Article 17 of the Referendum Law states that the President may, upon the Executive Yuan's resolution, call a referendum and submit questions regarding national security to the people, if, and only if, the country faces an external threat that is "likely" to cause a change in its sovereign status. The purpose of this provision, in political terms, is to respond, through democratic means, to a possible military threat from China, for instance by deploying military vessels to the Taiwan Strait, increasing the deployment of missiles on the Strait or taking any steps with intent to paralyse Taiwan's defence system.

The question is whether Taiwan was facing an external threat that was likely to cause change in its sovereign status when President Chen called the defence referendum. The conditions imposed on the President's power to call a referendum are that, first, there must be a resolution of the Executive Yuan, second, there is an external threat to the country, and finally, such a threat is likely to cause a change in the country's sovereign status. There is no doubt that it would be unlawful for the President to call a referendum if these conditions were not met. Such an unlawful act should lead to sanctions imposed on the President. The Referendum Law did not intend to give the President an unfettered right to submit issues on national security to the people by way of referendum.

24 A number of questions arise in relations to the calling of the defence referendum. The first question is whether the President has exercised the power conferred by the Referendum Law unreasonably. The second question is whether the Law provides effective remedies to act as a legal restraint on the President if there is an abuse of the power to call a defence referendum in a situation when the conditions laid down by the law are not fulfilled. This may be the case if, for instance, the President calls a referendum even if he has no reasonable grounds to believe that there is any threat, or likelihood of threat, to the national sovereign status.

The Referendum Law does not specify who, in which court, and against whom, may bring an action if the defence referendum is called without meeting the conditions laid by Article 17. Procedurally speaking, no one would appear to have standing to bring proceedings against the President if the referendum were called without the conditions being fulfilled. This is because, under administrative law, a person wishing to challenge the calling of the defence referendum under the Referendum Law would have to show that the calling of the referendum affects his or her legal rights and interests recognised by the law ${ }^{30}$. Furthermore, a referendum called by the President under Article 17 is unlikely to cause a constitutional dispute arising out of the conflict of constitutional functions between central and local authorities ${ }^{31}$, which can give rise to the local authorities' standings to bring proceedings to resolve the dispute. 

administrative discretion to the President to consider whether the conditions have been met. That is to say, that the President may call a defence referendum if, in his opinion, the country faces an external threat that is likely to cause change in the sovereign status. In this regard, the courts will have the power to scrutinise the President's decision to call a referendum by examining whether the opinion by the President could have reasonably been formed. Even if this is the case, the court is unlikely to question the detail of the decision and to scrutinise evidence in relation to the relevant facts. The question will not be whether the President misled the public or whether the President had the power to call a defence referendum. The judicial inquiry will not be whether the situation considered by the President poses a threat to Taiwan but whether the President has reasonable grounds to form the opinion that Taiwan's sovereign status is likely to be changed by the military, diplomatic, economic, or other kind of threat under consideration. Under this test, however, the President will have a rather wide room for manoeuvre. It is because "threat" is not necessarily confined to military action but may include non-military threats, for instance diplomatic efforts limiting Taiwan's international activities and likely to have a negative impact on its sovereign status. One example in this regard might be china's relentless efforts to persuade countries not to establish or to sever existing diplomatic ties with Taiwan. To take this even further, it may be subjectively reasonable for anyone to form an opinion (academic or personal) that China's economic rise could pose an economic threat to Taiwan. China's economic boom may have a destabilising effect on Taiwan's securities markets and pose a threat to the country's sovereign status. More realistically, it could be argued that circumstances such as the passing of the Anti-Secession law by the Chinese People's Congress in 2005 with a provision authorising the deployment of nonpeaceful means and other necessary measures to protect China's sovereignty and territorial integrity ${ }^{34}$, may justify a defence referendum being called. There are several national security issues that could potentially be submitted for referendum, such as those relating to the export of agricultural products to China and the "three (direct) links" with China. The Law does not seem to delineate rigid boundaries within which such power to call a defence referendum may be exercised.

In conclusion, it would appear that the judicial restraint to the President's power to call a referendum is, at best, weak. As a consequence, the only checks and balances in the system will be to resort to impeachment proceedings or to the recall provided for by the Constitution ${ }^{35}$. However, impeachment proceedings, which can produce political uncertainty, are surely means of last resort for any political party to hold the Government accountable.

Case study

China Perspectives, 65 | may - june 2006 
29 The importance of the issue of the legality of the defence referendum and of the effectiveness of judicial control over the power of the President to call it are illustrated by the court proceedings brought by Lien Chan and James Soong, the blue camp presidential candidates, after the election held on March 20th 2004, to have the result of the election set aside ${ }^{36}$. The argument advanced by Lien Chan and James Soong was that the defence referendum was illegally held and that it had the effect of distorting the fairness of the election process. The defence referendum should not have been held together with the presidential election. The case reached the Supreme Court, which dismissed it. The argument of the applicants failed on the grounds that, even if the referendum were illegal, there was no proof of a causal link between the alleged illegality and the results of the election. This case shows that the exercise of the power to call a referendum may be a contentious matter. This reinforces the conclusion that more clarity is needed as regards both the nature and the extent of the presidential power and the judicial control over its exercise.

After the election, not only have the people forgotten about their democratic right to vote in a referendum but, more importantly, the political parties have been busy with other matters. With the newly elected chairman of the KMT, and the consequential structural changes in the party ${ }^{37}$, it seems that the Referendum Law will no longer be the centre of political rows. The new KMT chairman may not wish to stick to old issues, somehow limiting the party's development of new policy initiatives. He may prefer to move away from the disputes stemming from the 2004 presidential election and focus on the 2008 presidential election in which many believe he will stand as presidential candidate $^{38}$. Party supporters now hoping for a 2008 election win are less concerned about the issue of the legality and legitimacy of the referendum. This will remain the case, on both sides of the political spectrum, until it is stirred up once again by other political parties. For the DPP, there are more important issues than looking back at the legality of the Referendum Law. In the lawsuit brought by the blue camp presidential candidates to annul the March 20th 2004 presidential elections, the Supreme Court of Taiwan upheld the results of the elections, despite some reservations over the legality of the defence referendum ${ }^{39}$. The DPP is uninterested in reopening this debate.

31 Although the political landscape has changed and moved away from the debate about the Referendum Law, this article has shown that legal problems ${ }^{40}$ arising out of the Referendum Law existed and exist. The Legislative Yuan should take further measures to revise the 2003 Referendum Law. First, the Law must clearly state whether it is enacted for the purpose of exercising the rights of initiative and referendum conferred by the Constitution ${ }^{41}$. Secondly, a distinction must be drawn between the failure of the referendum on the ground of quorum and the rejection of the proposal by a majority of "no" votes ${ }^{42}$. Thirdly, the Law should clearly state, for each type of referendum, whether the result will have legally binding force, especially as regards the referendum held for the purpose of Constitutional amendment ${ }^{43}$. Fourth, the Law should specify who, in which court, and against whom, can bring proceedings in respect of a referendum under Article 17 if the specified conditions have not been met ${ }^{44}$. In this way, the exercise of this important instrument of democracy will be brought in line with the principle of the supremacy of the Constitution and the rule of law that it embodies. 


\section{NOTES}

1. Albert Venn Dicey, Introduction to the Study of the Law of the Constitution, London, Macmillan, 1889.

2. Friedrich A. von Hayek, The Road to Serfdom, University of Chicago Press, 1980.

3. Joseph Raz, The Authority of Law: Essays on Law and Morality, Oxford, Clarendon Press, 1979.

4. The Referendum Law, art 2.

5. The Referendum Law, art 2.

6. The Referendum Law, art 17.

7. The Referendum Law, art 2(4).

8. The Referendum Law, art 17.

9. The Referendum Law, art 2.

10. Kuomintang (KMT) and the People's First Party (PFP) together are referred to as "the blue camp". The Democratic Progressive Party (DPP), the ruling party in Taiwan, and the Taiwan Solidarity Union (TSU) are referred to as the green camp.

11. Judicial Yuan Interpretation No. 520, January 15th 2001, http:// www.judicial.gov.tw/constitutionalcourt/EN/p03_01.asp?expno=520

12. Judicial Yuan Interpretation No. 499, March 4th 2000, http://www.judicial.gov.tw/ constitutionalcourt/EN/p03_01.asp?expno=499

13. Legislative Yuan Gazette, No 92, Item 54, December 2003.

14. The Referendum Bill, art 6. Many perceived this an instrument to pave the way for Taiwan independence justified in international law. That is to declare independence based on self-determination, a doctrine in international law, though not necessarily a popular one.

15. The United States is under an obligation to provide military weapons to Taiwan under the Taiwan Relations Act, which obliges her to provide weapons to Taiwan for her defence.

16. John J Tkacik Jr, “Taiwan's Missile Referendum”, The Heritage Foundation, January 21st 2004.

17. For the first question, there were $16,507,179$ registered votes, $7,452,340$ votes cast ( $45.15 \%$ of registered votes), 7,092,629 (95.17\% of votes cast), 6,511,216 "Yes" votes ( $91.80 \%$ of the valid votes cast) and 581,413 "No" votes ( $8.20 \%$ of the valid votes cast). For the second question, there were $7,444,148$ votes cast ( $45.10 \%$ of registered votes), $6,865,574$ valid votes (92.13\% of votes cast), 6,319,663 "Yes" votes ( $92.05 \%$ of valid votes cast), and 545,911 "No" votes (7.95 of the valid votes cast).

18. The Referendum Law 2003, art 2, 16, 31.

19. Arguably, this could have an impact on the proceedings brought by the blue camp presidential candidates to have the presidential election declared null and void. 20. The official translation of fujue is "referendum". In Chinese, fujue carries the meaning of submission for approval. For instance, any constitutional amendments initiated by other bodies such as the Legislative Yuan must be submitted to the National Assembly for approval.

21. The Constitution of the ROC, art. 17.

22. The Constitution of the ROC, art. 136.

23. This principle is stated in Article 2 of the Constitution. 
24. As Chen said, "Yet, we must bear in mind that historic and political circumstances confine us to an existing constitutional framework that now poses the most direct impediment to effective governance...Procedurally, we shall follow the rules set out in the existing Constitution and its amendments. Accordingly, after passage by the national legislature, members of the first and also the last Ad Hoc National Assembly will be elected and charged with the task of adopting the constitutional reform proposal as passed by the legislature, abolishing the National Assembly, and incorporating into the Constitution the people's right to referendum on constitutional revision". http://www.president.gov.tw/2_special/2004_520/subject3.html.

25. The Referendum Law 2003, art. 30.

26. The Constitution, art. 11.

27. The Constitution, art. 27, 28, 29, 30.

28. The Constitution, art. 174.

29. The Referendum Law, art. 17.

30. The Referendum Law, arts. 54, 55, 56, 57, 58, 59, 60, 61.

31. The Referendum Law, art. 54.

32. No. 329 of the Constitutional ruling.

33. For instance, the Constitutional Court has ruled that the meaning of "the existing national boundaries" of the territory of the Republic of China is a political question and declined to rule on the matter. Based on this approach, it is not clear whether a court would consider the question whether or not the country faces an external threat likely to cause change in its sovereign status. This may well be held to be a political question. 34. Anti-Secession Law of the PRC, Article 8. It is stated that in the event that the "Taiwan independence" secessionist forces should act under any name or by any means to cause the fact of Taiwan's secession from China, or that major incidents entailing Taiwan's secession from China should occur, or that possibilities for a peaceful reunification should be completely exhausted, the state shall employ non-peaceful means and other necessary measures to protect China's sovereignty and territorial integrity. The State Council and the Centre Military Commission shall decide on and execute the non-peaceful means and other necessary measures as provided for in the preceding paragraph and shall promptly report to the Standing Committee of the National People's Congress.

35. The Constitution of the ROC, art. 27, 97, 123.

36. The High Court of Taiwan, No. 4, 2004.

37. “Ma's Blue Ocean Strategy", Xinxinwen (The Journalist), No 963, August 22nd 2005.

38. Kathrine Hille "Taiwan's KMT Rubs Up Its Image", The Financial Times, September 10 th 2005.

39. High Court Judgement, No. 2, 2004; No. 4, 2004.

40. There, are, of course, a number of political problems. For instance, some suggest that the quorum of a $50 \%$ turnout was set too high to achieve any successful result. However, the quorum issue is a political question not a legal one. This article and its conclusions focus on the legal problems.

41. The Constitution of the ROC, art. 17; The Referendum Law, arts. 1 and 2.

42. The Referendum Law 2003, art. 30.

43. The Referendum Law 2003, art. 2; Constitution of the ROC, arts. 174 and 175.

44. The Referendum Law 2003, art. 17. 


\section{RÉSUMÉS}

This article argues that the Taiwan Referendum Law 2003 and the defence referendum held in 2004 raise a number of legal problems that deserve closer examination. It discusses the history of the Referendum Law from both legal and political viewpoints and argues that a functional and legitimate referendum must be carried out in compliance with the rule of law and the supremacy of the Constitution. The author identifies four main areas of concern, taking into account the Constitutional Amendment in 2005. First, the Referendum Law contained unconstitutional provisions that were not challenged before the defence referendum was held. Secondly, the Referendum Law should have expressly relied on the Constitution as its legal basis. Thirdly, the Referendum Law does not clearly determine the legal effects of the referendum. Fourthly, it does not contain adequate legal restraints on the President's power to call a defence referendum. These legal issues have been raised in politically oriented cases in the courts. This article, however, concludes that the initiative to rectify the legal problems of the Referendum Law should lie with the Legislative Yuan of Taiwan. 